\title{
A reporter gene vector to investigate the regulation of glutamine synthetase in Bacteroides fragilis Bf1
}

\author{
VALERIE R. Abratt, ${ }^{1}$ Harold ZAPPE ${ }^{2}$ and DaVid R. WoOdS ${ }^{1 *}$ \\ ${ }^{1}$ Department of Microbiology, University of Cape Town, Rondebosch 7700, South Africa \\ ${ }^{2}$ Virginia Polytechnic and State University, Blacksburg, Virginia 24061, USA
}

(Received 6 April 1992; revised 25 August 1992; accepted 7 September 1992)

\begin{abstract}
The Clostridium acetobutylicum eglA gene, encoding a $\beta$-1,4-endoglucanase (EG), was shown to be a useful reporter gene for the study of gene expression in Bacteroides fragilis. The eglA reporter gene has the advantages that it can be easily identified in both Escherichia coli and $B$. fragilis on agar media containing carboxymethylcellulose, and EG production can be rapidly quantified in liquid medium. Since the $B$. fragilis glutamine synthetase (GS) is inactivated in permeabilized cells and cell extracts, the eglA reporter gene was used to study the regulation of GS production in $B$. fragilis. Gene fusions containing the GS $g \ln A$ promoter region fused to the promoterless $e g l A$ gene showed that $g \ln A$ expression was regulated by nitrogen in $B$. fragilis at the transcriptional level. A $g \ln A$ upstream region containing a near-perfect direct repeat sequence was essential for efficient GS expression and for regulation by nitrogen.
\end{abstract}

\section{Introduction}

Bacteroides fragilis is a strictly anaerobic, pathogenic bacterium found in the human digestive tract (Salyers, 1984). It has been proposed that the production of certain proteases may play a role in the pathogenicity of this organism (Macfarlane et al., 1992). Furthermore, Gibson \& Macfarlane (1988) have shown that the levels of nitrogen in the growth medium influence protease activity. The mechanisms used by $\boldsymbol{B}$. fragilis to assimilate ammonia are, therefore, of interest.

Studies on the pathways of nitrogen assimilation in $B$. fragilis are still at an early stage. Yamamoto et al. (1984, 1987) have demonstrated the activities of both NADPHand NADH-linked glutamate dehydrogenase (GDH: EC 1.4.1.3) and glutamine synthetase (GS: EC 6.3.1.2) in extracts of $B$. fragilis ATCC 23745 cells, but very low activity of NADPH-dependent glutamate synthase and no activity of alanine dehydrogenase. Both GDH and GS were regulated by the levels of ammonia in the growth medium, with higher expression of both being detected under nitrogen-limiting conditions than when excess nitrogen was present. This indicated a novel

* Author for correspondence. Tel. (021) 6503270 ; fax (021) 650 4023; e-mail sec@micro.uct.ac.za.

Abbreviations: DIG, digoxygenin; EG, endoglucanase; GDH, glutamate dehydrogenase; GS, glutamine synthetase. mechanism of nitrogen assimilation in $B$. fragilis differing from that of other organisms, where GS is expressed under low, and GDH under high nitrogen conditions.

The GS gene $(g \ln A)$ from the clinical isolate $B$. fragilis Bf1 (Mossie et al., 1979) has been cloned (Southern et al., 1986), the nucleotide sequence determined (Hill et al., 1989), and the GS protein characterized (Southern et al., 1987). The $g \ln A$ gene and its corresponding protein were shown to possess certain novel structural and molecular characteristics differing from the GS enzymes of prokaryotes, eukaryotes and archaeobacteria (Hill et al. 1989). Because of these differences, Hill et al. (1989) proposed that the GS of $B$. fragilis $\mathrm{Bf} 1$ belonged to a new class of GS enzymes termed GSIII.

It is not possible to study the regulation of GS in $B$. fragilis Bf1 by assaying GS enzyme activity directly since Southern et al. (1987) showed that GS activity was specifically inhibited in permeabilized $B$. fragilis $\mathrm{Bf} 1$ cells and cell extracts. Addition of $B$. fragilis cell-free extract to the cloned $B$. fragilis $g \ln A$ gene product expressed in the Gln $\mathrm{A}^{-}$E. coli strain YMC11 completely inhibited GS activity, whereas it had no effect on the GS activity obtained from the $\mathrm{Gin}^{+}$wild-type E. coli strain YMCl0. However, the presence and regulation of GS in B. fragilis Bf1 cells was observed by Southern et al. (1987), who used Western blot analysis to detect the enzyme, and showed that the levels of GS enzyme varied depending on the nitrogen content of the growth medium. The level of GS enzyme was higher under conditions of nitrogen 
Table 1. Bacterial strains and plasmids

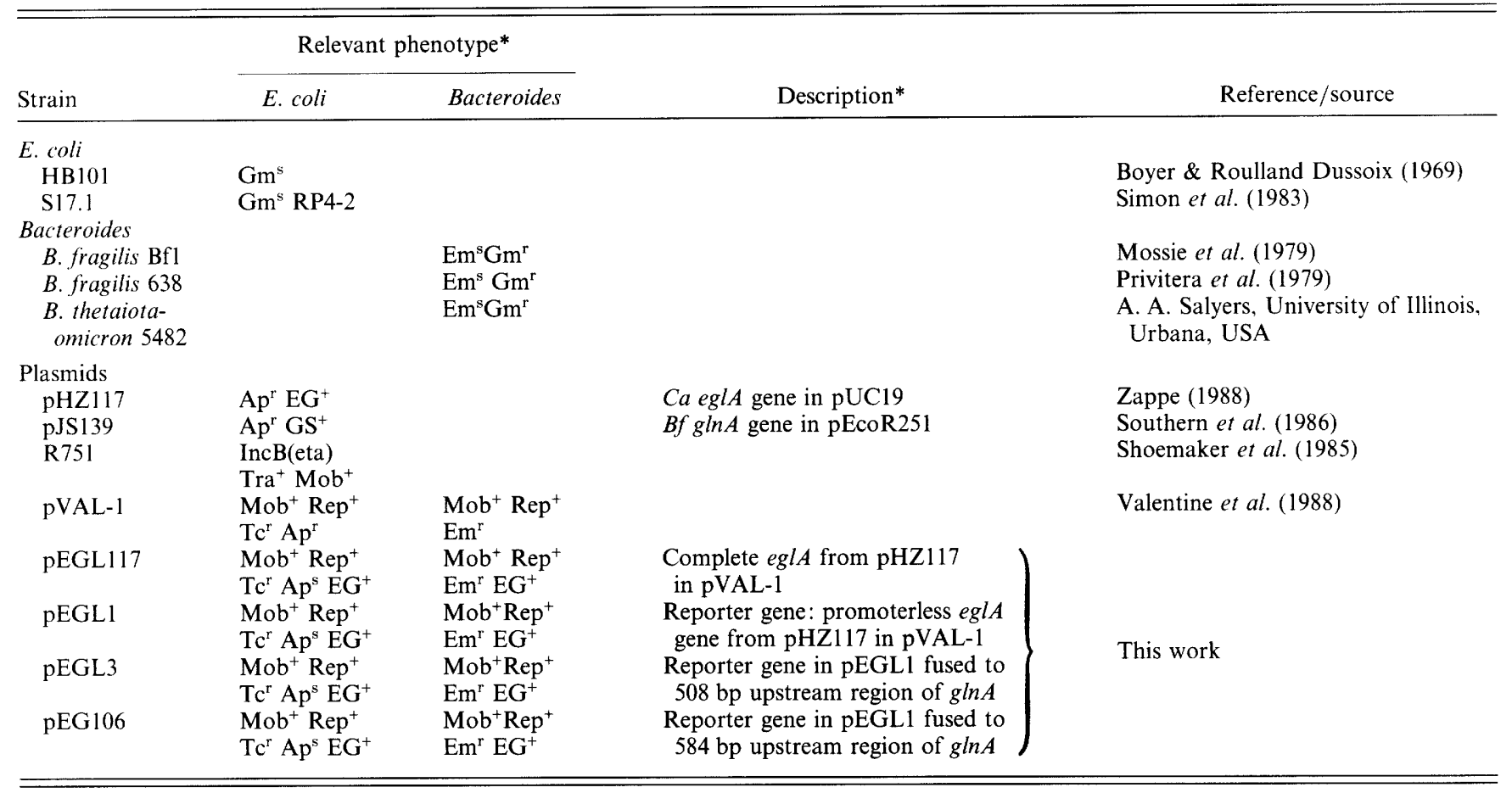

* Abbreviations used: r, resistance; s, sensitivity: Ap, ampicillin; Tc, tetracycline; Em, erythromycin; Gm, gentamicin; Tp, trimethoprim; Tra. ability to self-transfer; Mob, able to be mobilized by a conjugative element; Rep, able to replicate; Inc, plasmid incompatibility group; EG. endoglucanase (eglA gene); GS, glutamine synthetase (glnA gene); Ca, C. acetobutylicum P262; Bf, B. fragilis Bf1.

limitation. It was not, however, known whether the enzyme was being regulated at the level of transcription or translation.

To study the regulation of GS in B. fragilis $\mathrm{Bfl}$, we have developed a reporter gene vector using the promoterless $\beta$-1,4-endoglucanase gene $(\mathrm{eglA})$ of Clostridium acetobutylicum P262 (Zappe et al., 1986, 1988). This vector has been used to identify the promoter region of the $B$. fragilis $\mathrm{Bfl}$ GS involved in its regulation by nitrogen in various Bacteroides species.

\section{Methods}

Bacterial strains, plasmids and growth conditions. Bacterial strains and plasmids are shown in Table 1. B. fragilis Bfl was described by Mossie et al. (1979) and was used by Southern et al. $(1986,1987)$ for the cloning of the $g \ln A$ gene. All Bacteroides strains were maintained anaerobically (Abratt et al., 1985) at $37^{\circ} \mathrm{C}$ on supplemented brain heart infusion (BHI) agar (Holderman et al., 1977), with the addition of erythromycin $(\mathrm{Em})\left(100 \mu \mathrm{g} \mathrm{ml} \mathrm{m}^{-1}\right)$ for the maintenance of transconjugants. Pre-cultures for nitrogen regulation studies were grown for $16-18 \mathrm{~h}$ in BHI broth. Escherichia coli strains were grown at $37^{\circ} \mathrm{C}$ on Luria-Bertani (LB) agar (Maniatis et al., 1982) supplemented with ampicillin (Ap) $\left(100 \mu \mathrm{g} \mathrm{ml}^{-1}\right)$, trimethoprim (Tp) $\left(200 \mu \mathrm{g} \mathrm{ml}^{-1}\right)$ or tetracycline (Tc) $\left(10 \mu \mathrm{g} \mathrm{ml}^{-1}\right)$ for the maintenance of plasmids. Precultures of Bacteroides and E. coli strains for conjugation experiments were grown for 16-18 h in trypticase yeast glucose (TYG) broth (Valentine et al., 1988), pre-reduced when required for anaerobic growth, and conjugation was carried out on TYG agar with anaerobic selection of transconjugants on TYG containing Em $\left(10 \mu \mathrm{g} \mathrm{ml}^{-1}\right)$ and gentamicin $(\mathrm{Gm})\left(200 \mu \mathrm{g} \mathrm{m}^{-1}\right)$. Nitrogen regulation studies were carried out in minimal medium (MM) broth (Varel \& Bryant, 1974) modified as follows: volatile fatty acids and casitone were omitted; vitamin $\mathbf{B}_{12}$ was the only vitamin $\mathrm{B}$ added; higher final concentrations of menadione ( $\left.0.5 \mathrm{mg} \mathrm{ml}^{-1}\right)$, haemin $\left(5 \mathrm{mg} \mathrm{ml}^{-1}\right), \mathrm{Na}_{2} \mathrm{CO}_{3}\left(1 \mathrm{mg} \mathrm{ml}^{-1}\right)$ and $\mathrm{CoCl}_{2} \cdot 6 \mathrm{H}_{2} \mathrm{O}\left(0.01 \mathrm{mg} \mathrm{ml}^{-1}\right)$ were used; phosphate buffer $(0 \cdot 1 \mathrm{M}$; $\mathrm{pH} \mathrm{7.0)}$ was used instead of $\mathrm{KH}_{2} \mathrm{PO}_{4}$. The medium was supplemented with 7.5 or $0.05 \mathrm{~mm}-\left(\mathrm{NH}_{4}\right)_{2} \mathrm{SO}_{4}$ (high or low nitrogen, respectively).

Preparation and analysis of nucleic acids. Unless otherwise stated, all constructs were derived and analysed in $E$. coli $\mathrm{HBl} 101$ prior to conjugation into Bacteroides. Plasmid DNA was isolated according to the method of Ish-Horowitz \& Burke (1981), and cloning and transformation in E. coli were carried out as described by Maniatis $e t$ al. (1982). Restriction endonucleases were used according to the manufacturers' instructions. Total cellular RNA was extracted from $10 \mathrm{ml}$ or $100 \mathrm{ml}$ cultures of early exponential phase $E$. coli or B. fragilis cells, respectively (Aiba et al., 1981).

Conjugation procedures. Bacterial matings were carried out as described by Valentine et al. (1988), using $E$. coli $\mathrm{HB10I}(\mathrm{R} 751)$ or $E$. coli $\mathrm{S} 17.1$ as donors, and Bacteroides thetaiotaomicron 5482, B. fragilis 638 and $B$. fragilis $\mathrm{Bf} 1$ as recipients. A donor-to-recipient ratio of $1: 5$ was used throughout.

Plasmid construction. The construction of the reporter gene shuttle vector, pEGL1, and its derivatives is shown in Table 1, and Figs 1 and 2. The SspI-PstI fragment of the plasmid pHZ117 (Zappe, 1988) containing the $C$. acetobutylicum endoglucanase structural gene (eglA) and $21 \mathrm{bp}$ upstream of the TTG start codon (including the ribosomebinding site, but excluding the major promoter region as determined by 

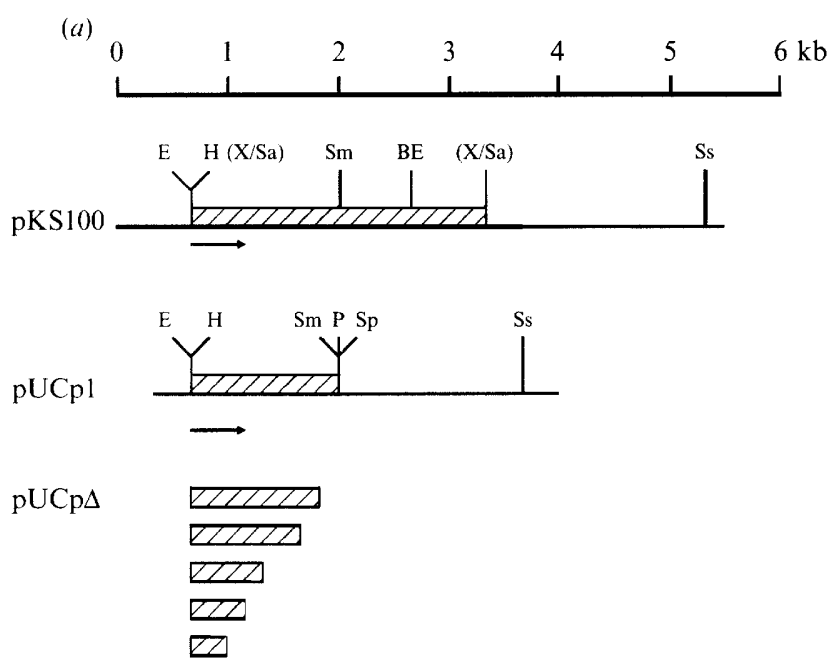

(b)

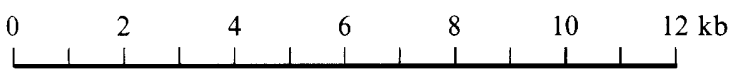

$\mathrm{pHZ} 117$

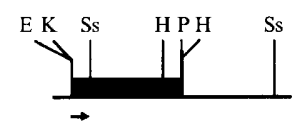

pHZ117

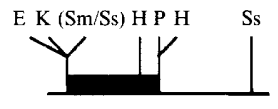

pEGL1

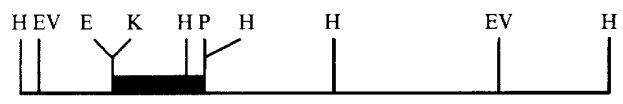

pEGL106

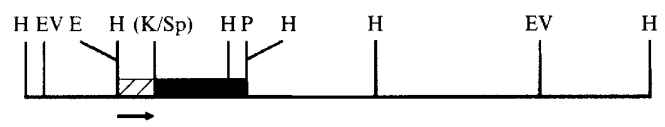

Fig. 1. Construction and restriction endonuclease maps of pKS100,

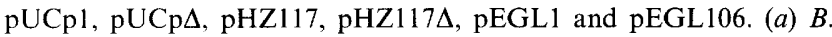
fragilis glnA deletion plasmids; (b) $C$. acetobutylicum eglA reporter gene and fusions. Abbreviations: E, EcoRI; H, HindIII; X, XhoI; Sa, SalI; Sm, SmaI ; BE, BstEII; Ss, SspI ; P, PstI ; K, KpnI ; EV, EcoRV. Single lines, vector regions; hatched bars, $g \ln A$; solid bars, eglA; arrows, orientation of the $g \ln A$ and $e g l A$ promoter regions.

primer extension; V. Abratt, unpublished results) was subcloned between the SmaI and PstI restriction sites of $\mathrm{pUC19}(\mathrm{pHZ117 \Delta})$. The $E c o$ RI $-P_{s t}$ I fragment of $\mathrm{pHZ117 \Delta}$ was then cloned between the EcoRI and $P s t \mathrm{I}$ sites of pVAL-1 to form the promoterless reporter gene shuttle vector $\mathrm{pEGL1}$

Promoter fusions were constructed using the $B$. fragilis $g \ln A$ promoter region. The $2.4 \mathrm{~kb}$ XhoI fragment of pJS139 (Southern et al., 1986) was cloned into the Bluescript (pKS) (Stratagene) Sall site in the same orientation (pKS100). The $1.25 \mathrm{~kb} E c o \mathrm{RI}-S m a \mathrm{I}$ fragment of pKS100 containing the $g \ln A$ upstream region $(615 \mathrm{bp})$ and part of the structural gene ( 635 bp) (Fig. 1a) was subcloned between the EcoRI and SmaI sites of pUC19 (pUCp1). The latter plasmid was subjected to exonuclease III digestion from the PstI site (Henikoff, 1984) to create a set of deletion plasmids containing various fragments of the upstream region of the $g \ln A$ gene $(\mathrm{pUCp} \Delta)$. These plasmids were pooled. digested with EcoRI and $S p h \mathrm{I}$ (blunt) and cloned between the EcoRI and $K p n \mathrm{I}$ (blunt) sites of pEGLl. Recombinant plasmids conferring increased endoglucanase (EG) activity on $E$. coli transformants were selected for sequence analysis and conjugation into the various Bacteroides recipients.

The endoglucanase gene cloned from $C$. acetobutylicum P262 $(\mathrm{eg} / \mathrm{A}$ and $280 \mathrm{bp}$ of upstream region) was tested for anaerobic expression from its own promoter in Bacteroides by subcloning the $1.4 \mathrm{~kb}$ $E c o$ RI-PstI fragment from $\mathrm{pHZ} 117$ between the EcoRI and $P_{s t} \mathrm{l}$ sites of pVAL-1 (pEGL117).

Endoglucanase activity assays. Colonies grown on $\mathrm{LB}(\mathrm{Tc})$ agar $(E$ coli transformants) or $\mathrm{BHI}(\mathrm{Em})$ agar (Bacteroides transconjugants) containing $0 \cdot 1 \%$ medium-viscosity carboxymethylcellulose (CMC) were tested for CMCase activity by the Congo Red method (Teather \& Wood, 1982). Quantitative determination of promoter expression in Bacteroides cells was done by inoculating cells from a $16-18 \mathrm{~h} \mathrm{BHI}$ preculture into pre-warmed MM (50-fold dilution) supplemented with high $(7.5 \mathrm{~mm})$ or low $(0.05 \mathrm{~mm})$ concentrations of $\left(\mathrm{NH}_{4}\right)_{2} \mathrm{SO}_{4}$. Cellfree extracts were prepared by harvesting samples $(100 \mathrm{ml})$ of cells by centrifugation at various times during the growth cycle. The cells were washed with phosphate/citrate (PC) buffer $\left(50 \mathrm{~mm}-\mathrm{K}_{2} \mathrm{HPO}_{4}\right.$. $14 \mathrm{~mm}$-citric acid, pH $6.0 ; 100 \mathrm{ml}$ ), resuspended in the same buffer $(2 \mathrm{ml})$, and disrupted by sonication. EG activity was determined by the dinitrosalicylic acid (DNS) assay for the release of glucose equivalents from $1 \%(\mathrm{w} / \mathrm{v}) \mathrm{CMC}$ during $30 \mathrm{~min}$ incubation at $50^{\circ} \mathrm{C}$ (Ghose, 1987). Protein concentrations were determined using the biuret protein assay (Gornall et al., 1949). The repression ratio relating EG activity under high: low nitrogen conditions was calculated.

Sequence analysis and primer extension studies. DNA sequencing was done by the method of Sanger et al. (1977). Synthetic oligonucleotides (5'-ATAGCTCTTGTAGTGCG-3' for $g \ln A$ and $5^{\prime}$ CATAACTAATGTTGC- $3^{\prime}$ for $e g l A$ ) were used as internal primers. Transcriptional start points of the C. acetobutylicum eglA gene and the $B$. fragilis glnA gene were determined using $E$. coli $\mathrm{HB} 101$ (pHZ117) and B. fragilis Bf1 total RNA respectively (Hill et al., 1989) (Fig. 2).

RNA hybridization analysis. Equal amounts of total RNA (10 mg $\mathrm{ml}^{-1}$ ) from $B$. fragilis $\mathrm{Bfl}(\mathrm{pEGL106})$, grown under conditions of high $(7.5 \mathrm{~mm})$ or low $(0.05 \mathrm{mM})\left(\mathrm{NH}_{4}\right)_{2} \mathrm{SO}_{4}$, were fixed to Hybond- ${ }^{+}$ hybridization membrane (Amersham) according to the manufacturer's instructions, using a dot-blotting apparatus. Gel-purified DNA containing the EcoRI-PstI fragment of pHZ117 or the EcoRI-BstEII fragment of pKS100 (Fig. $1 a, b$ ) were prepared as probes for $e g / A$ or $g \ln A$ mRNA respectively by the DNA random-priming digoxygenin (DIG) method (DNA Nonradioactive Labelling Kit, Boehringer Mannheim Biochemica). The labelled probes were hybridized $\left(68^{\circ} \mathrm{C}\right)$ to the mRNA. Hybridization and chemiluminescent detection were carried out according to the manufacturer's instructions (DIG Luminescent Detection Kit, Boehringer Mannheim Biochemica). Graphical representation of the data was obtained by scanning the autoradiographs using a densitometer, and the peak area was calculated by triangulation of the peaks.

\section{Results}

Expression of the C. acetobutylicum P262 endoglucanase gene (eglA) in Bacteroides

Plasmids pVAL-1 (shuttle vector), pEGL117 (shuttle vector carrying intact $e g l A$ ), and pEGLl (shuttle vector carrying the promoterless eglA reporter gene) (Table 1) were conjugated from E. coli $\mathrm{HB} 101(\mathrm{R} 751)$ or S17.1 
(a) B. fragilis $\mathrm{Bfl} g \ln A$ promoter sequence

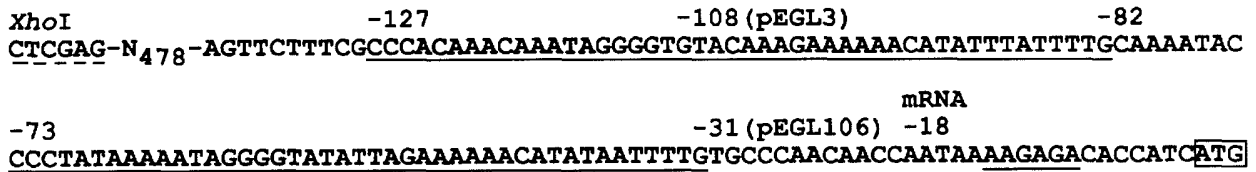

(b) C. acetobutylicum $\mathrm{P} 262$ eglA reporter gene

$\begin{array}{cc}\text { (SmaI/SSPI) } & \text { weak mRNA } \\ \text { *gcatggtacCGATTATAATAGGGGGTATTAACTTGTTTTCAAAAA }\end{array}$

Fig. 2. Construction of $g \ln A$ promoter fusions to the eglA reporter gene. Upstream sequences of the $g \ln A$ gene promoter region (a) were fused to the promoterless $e g l A$ reporter gene $(b)$. Fusion pEGL3 contained the $X h o I$ to -108 bp region, and pEG106 the $X h o I$ to $-31 \mathrm{bp}$ region fused upstream of the ribosome-binding site of the eglA reporter gene. Abbreviations and symbols: Lower case, vector sequence; $\mathrm{N}$, nucleotide; single underline, direct repeat sequences -31 to $-73 \mathrm{bp}$ and -82 to $-127 \mathrm{bp}$ upstream of the glnA translation start; double underline, ribosome binding site; dashed underline, restriction endonuclease cloning sites; box, transcription start point; mRNA, transcription start points; *, position at which the $g \ln A$ promoter sequences are fused to the promoterless $e g / A$ reporter gene.

Table 2. Production of EG in high-and low-nitrogen media by B. fragilis Bf1 cells containing $p V A L-1, p E G L 117, p E G L 1, p E G L 3$, or $p E G L 106$

The mean results of at least three separate experiments are shown; the deviation from the mean did not exceed $15 \%$.

\begin{tabular}{|c|c|c|c|c|c|c|c|c|c|}
\hline \multirow{3}{*}{$\begin{array}{l}\text { Growth stage*.. } \\
\text { Medium } \dagger \ldots \\
\text { Plasmid }\end{array}$} & \multicolumn{9}{|c|}{ EG activity [nmol glucose equiv. (mg protein $)^{-1} \min ^{-1}$ ] } \\
\hline & \multicolumn{3}{|c|}{ Early } & \multicolumn{3}{|c|}{ Mid } & \multicolumn{3}{|c|}{ Late } \\
\hline & $\mathrm{H}$ & $\mathrm{L}$ & $\mathrm{H} / \mathrm{L} \ddagger$ & $\mathrm{H}$ & L & $\mathrm{H} / \mathrm{L}_{+}^{+}$ & $\mathrm{H}$ & $\mathrm{L}$ & $\mathrm{H} / \mathrm{L}+$ \\
\hline pVAL-1 & 0 & 0 & & 0 & 0 & & 0 & 0 & \\
\hline pEGL117 & $48 \cdot 3$ & $54 \cdot 4$ & 0.88 & $25 \cdot 7$ & $23 \cdot 0$ & $1 \cdot 10$ & $32 \cdot 5$ & $39 \cdot 4$ & 0.82 \\
\hline pEGLl & 0 & 0 & & $7 \cdot 7$ & $8 \cdot 2$ & 0.93 & $7 \cdot 2$ & $8 \cdot 5$ & 0.84 \\
\hline pEGL3 & $8 \cdot 3$ & $20 \cdot 1$ & 0.41 & $17 \cdot 5$ & $6 \cdot 5$ & 2.69 & 7.9 & $9 \cdot 1$ & 0.87 \\
\hline pEGL106 & $29 \cdot 1$ & $59 \cdot 3$ & 0.49 & $8 \cdot 7$ & $23 \cdot 2$ & 0.37 & $1 \cdot 6$ & $32 \cdot 1$ & 0.05 \\
\hline
\end{tabular}

* Bacteria were harvested at early $(4-5 \mathrm{~h})$, mid $(6-7 \mathrm{~h})$ and late $(9-10 \mathrm{~h})$ exponential growth as described in Methods.

$\dagger \mathrm{MM}$ was supplemented with $7.5 \mathrm{mM}(\mathrm{H})$ or $0.05 \mathrm{mM}(\mathrm{L})\left(\mathrm{NH}_{4}\right)_{2} \mathrm{SO}_{4}$.

$\$$ Repression ratio of EG expression under high:low nitrogen conditions.

donor cells into B. thetaiotaomicron 5482 , B. fragilis 638 , and $B$. fragilis $\mathrm{Bf} 1$. Em-resistant transconjugants were analysed for conjugation frequency, the presence of the plasmid in the cytoplasm, and endoglucanase activity on $\mathrm{BHI}-\mathrm{CMC}$ and MM-CMC agar plates.

The conjugation frequency (number of transconjugants/number of recipients) was higher for $B$. thetaiotaomicron $\left(5 \times 10^{-5}\right)$ than for the $B$. fragilis strains $\left(3 \times 10^{-7}\right)$. All transconjugants carried the shuttle vector in the cytoplasm, indicating that insertion into the chromosome had not occurred. None of the Bacteroides strains containing pVAL-1 produced EG after growth on BHI- or MM-CMC agar. Both B. fragilis 638(pEGL117) and $B$. fragilis $\mathrm{Bf} 1(\mathrm{pEGL117)}$ produced $\mathrm{EG}$ on $\mathrm{BHI}-$ and MM-CMC, while B. thetaiotaomicron 5482(pEGL117) produced very low levels of EG as detected by the size of the zones in the Congo red agar plate assay. The Bacteroides strains containing pEGLl showed markedly less EG activity than those containing pEGL117. The residual low EG activity conferred on $B$. fragilis by pEGL1 was thought to be due to a weak promoter situated $7 \mathrm{bp}$ upstream from the eglA gene TTG start codon (Fig. 2). These results indicated that the $C$. acetobutylicum eglA gene was expressed from its own promoter in B. fragilis.

Analysis of the glutamine synthetase promoter fusions

Production of EG by two recombinant plasmids containing different regions of the $g \ln A$ upstream region fused to the reporter gene was studied (Fig. 2, Table 2). Plasmid pEGL106 contained $584 \mathrm{bp}$ of the $g \ln A$ up- 
stream region from position -31 from the ATG start to the upstream $X h o I$ site. This included the nearly perfect direct repeat sequences (positions -31 to $-127 \mathrm{bp}$ from the ATG start) observed by Hill et al. (1989). Plasmid pEGL3 contained $508 \mathrm{bp}$ of the $g \ln A$ upstream region from position -108 from the ATG start to the upstream XhoI site.

These plasmids were conjugated into the Bacteroides recipients and EG was assayed qualitatively by activity on BHI-CMC agar plates, and quantitatively in MM broth under high and low nitrogen conditions (Table 2). pEGL106 conferred significant EG activity on the Bacteroides recipients as indicated by the Congo red plate assay method. The level of activity was greatest in $B$. fragilis $\mathrm{Bf} 1$ and $B$. fragilis 638 (largest zones), and very low in $B$. thetaiotaomicron 5482 . $B$. fragilis strains containing pEGL3 produced small but detectable zones on agar plates stained with Congo red, but no activity was detected in B. thetaiotaomicron 5482(pEGL3).

The activity of EG was quantified as a measure of $\mathrm{eglA}$ gene expression under the control of the $g \ln A$ promoter. All three Bacteroides strains containing the two putative promoter fusions were grown in MM broth cultures from early to late exponential phase under conditions of high and low nitrogen. Bacteroides strains containing pVAL-1, pEGL117 or pEGL1 were used as controls. Maximum expression of the reporter gene in $B$. fragilis Bfl(pEGL106) occurred at early exponential phase (Table 2). B. fragilis $\mathrm{Bf1}$ (pEGL106) produced more EG in the low-nitrogen medium than in the high-nitrogen medium. Regulation by nitrogen was greatest at late exponential phase, and repression ratios of EG activity were $0.49,0.37$ and 0.05 for early, mid- and late exponential phase, respectively (Table 2). Production of EG by $B$. fragilis $\mathrm{Bf1}(\mathrm{pEGL} 3$ ) in the early exponential phase was lower than that of B. fragilis Bf1(pEGL106), and it showed no consistent regulation by the levels of nitrogen in the growth medium. EG expression in $B$. fragilis $\mathrm{Bf} 1$ (pEGL3) varied in the low- and high-nitrogen media such that in early exponential phase more EG was produced in cells grown in the low-nitrogen medium whereas in mid-exponential phase the opposite was observed. This result indicates that, while the $\operatorname{gn} \mathrm{A}$ promoter region present in pEGL3 is still functional during strong exponential growth of the cells, an essential region involved in nitrogen regulation has been disrupted and is no longer present. $B$. fragilis $\mathrm{Bfl}(\mathrm{pEGL} 1)$ produced low levels of EG, presumably from the weak $C$. acetobutylicum mRNA transcription start (Fig. 2) still present in the reporter gene. Similar amounts of EG were produced in high- and low-nitrogen media in midand late exponential phase cells. No EG activity was detected in $B$. fragilis $\mathrm{Bf1}(\mathrm{pVAL}-1) . \quad B$. fragilis Bfl(pEGL117) cells produced relatively high levels of

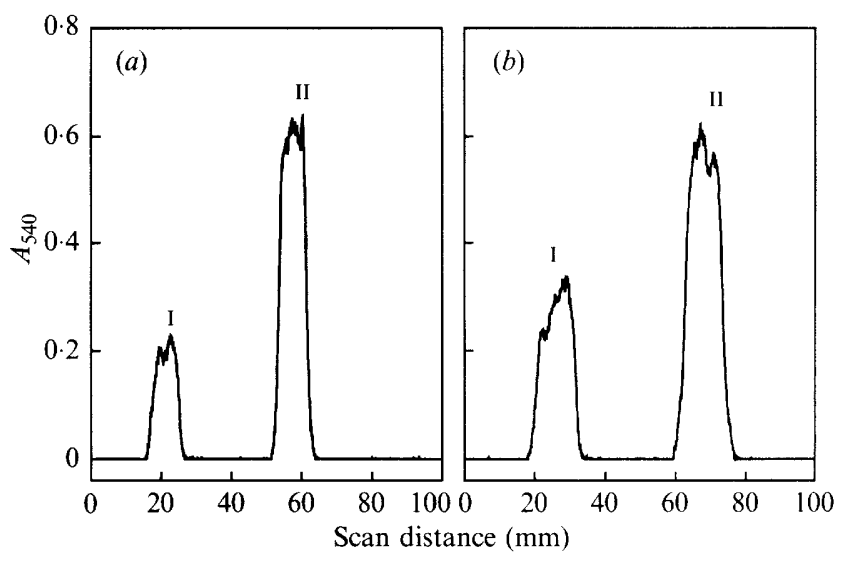

Fig. 3. Production of $g \ln A(a)$ and $e g l A(b)$ mRNA in early exponential phase cells of $B$. fragilis $\mathrm{Bf1}$ (pEGL106). Equal amounts of total mRNA from cells grown in high $(7.5 \mathrm{~mm})$ or low $(0.05 \mathrm{~mm})\left(\mathrm{NH}_{4}\right)_{2} \mathrm{SO}_{4} \mathrm{MM}$ were hybridized to DIG-labelled internal DNA fragments of the $\mathrm{eg} / \mathrm{A}$ or $g \ln A$ genes and the levels of mRNA transcripts determined by densitometer scans of the chemiluminescent autoradiographs. Representative results from three experiments are shown. I, high nitrogen; II, low nitrogen.

EG activity which were not markedly affected by growth in high- or low-nitrogen medium and which reached a maximum in early exponential phase (Table 2). Similar results were obtained with $B$. fragilis 638 containing the various plasmids, but very low levels of activity with no regulation by nitrogen occurred in $B$. thetaiotaomicron 5482 containing the various plasmids (results not shown).

\section{$R N A$ analysis}

RNA isolated from $B$. fragilis $\mathrm{Bfl}(\mathrm{pEGL106)}$ at early exponential phase was used to determine whether the observed regulation of EG activity was occurring at the level of transcription, and whether the reporter gene was being co-regulated with the chromosomal $g \ln A$ gene. Hybridization of equal amounts of total RNA, extracted from B. fragilis $\mathrm{Bf1}(\mathrm{pEGL106}$ ), to both $e g l A$ and $g \ln A$ internal DNA probes showed that both the $e g l A$ and glnA mRNA transcripts occurred at higher levels under low-nitrogen conditions than when there was excess nitrogen present (Fig. 3). The nitrogen repression ratios (high:low) at the mRNA level, as calculated from the peak absorbances of the scans, were 0.52 and 0.43 for $g \ln A$ and $e g l A$, respectively.

\section{Discussion}

The $B$. fragilis reporter gene system described in this work facilitated the rapid quantitative and qualitative assay of promoter activity in both $E$. coli and B. fragilis. Previously described vectors of this type have had certain 
drawbacks. The promoterless erythromycin resistance vector pFD214 (Smith, 1987), can be used qualitatively, but activity is difficult to quantify routinely, and promoter constructs cannot be tested in $E$. coli. The $\beta$ glucuronidase reporter gene vectors pMJF-2 and pMJF3 (Feldhaus et al., 1991) can be used quantitatively, but activity cannot be observed anaerobically in plate assays.

We have used the $C$. acetobutylicum P262 eglA gene, which encodes CMCase activity, to quantify promoter functions in a range of Bacteroides strains. It was shown that only low levels of CMCase activity could be detected when $e g l A$ was functioning off either the $C$. acetobutylicum eglA promoter or the $B$. fragilis $\mathrm{Bfl} g \ln A$ promoter in $B$. thetaiotaomicron, and no regulation of the $g \ln A$ promoter by nitrogen was observed. Good expression of the eglA gene was observed in B. fragilis strains, with repression of the $g \ln A$ occurring under highnitrogen conditions. This is of interest since it indicates possible differences in promoter recognition mechanisms in the two species. This supports the theory that the colonic Bacteroides species are genetically distinct from one another (Salyers, 1984).

Very little is known about Bacteroides promoters, and promoter fusion analysis of the $B$. fragilis $\mathrm{Bfl} g \ln A$ upstream region can contribute useful information in this regard. Hill et al. (1989) identified a putatitive Shine-Dalgarno (Shine \& Dalgarno, 1976) ribosomebinding site, mRNA transcriptional starts and an ATG start codon (Fig. 2). In this study it was shown that promoter expression and nitrogen regulation of the $g \ln A$ gene in B. fragilis $\mathrm{Bf1}$ appeared to be dependent on the -31 to $-107 \mathrm{bp}$ upstream region of the $g \ln A$ gene, spanning most of the two direct repeat sequences $(-31$ to $-127 \mathrm{bp}$ ), since efficient expression and nitrogen regulation of eglA did not occur in $B$. fragilis $\mathrm{Bf} 1$ (pEGL3) which contained only the -108 to $-127 \mathrm{bp}$ portion of this region.

The observed regulation of eglA expression by nitrogen in $B$. fragilis Bfl cells containing pEGL106 is considered to be an accurate reflection of $g \ln A$ expression in $B$. fragilis $\mathrm{Bf} 1$ since the production of $\mathrm{EG}$ by cells containing the control plasmid, pEGL117, carrying the eglA gene expressed from the C. acetobutylicum P262 promoter was not regulated by variations in the level of nitrogen in the growth medium. Furthermore, hybridization analysis of the mRNA transcripts produced by pEGL106 and the chromosomal $g \ln A$ gene in $B$. fragilis $\mathrm{Bf} 1$ showed that they were both regulated by nitrogen at the level of transcription. While the exact levels of EG produced by the multicopy $\operatorname{gln} A::$ eglA fusion plasmid pEGL106 cannot be directly compared quantitatively with the GS produced from the chromosomal $g \ln A$ gene, the nitrogen repression ratios of each gene (high: low) at the mRNA level, as calculated by peak triangulation of the scans, may be directly compared. These were of approximately the same order of magnitude for both the chromosomal $g \ln A$ gene and the $e g l A$ reporter gene functioning off the $g \ln A$ promoter (pEGL106) $(0.52$ and 0.39 respectively). This correlated with the repression ratio for EG enzyme activity in $B$. fragilis $\mathrm{Bf} 1(\mathrm{pEGL106})(0 \cdot 49)$, assayed from the same cell samples.

These studies on the expression and regulation of the $B$. fragilis $\mathrm{Bf} 1 \mathrm{~g} \ln A$ gene, which could not be assayed by conventional methods due to inhibition of GS activity in cell extracts, correlate with the findings of Yamamoto et al. (1984) that GS activity in B. fragilis ATCC 23745 was regulated by nitrogen, and that higher levels of $g \ln A$ expression occurred under conditions of limiting nitrogen.

The $C$. acetobutylicum $\mathrm{P} 262$ eglA reporter gene shuttle vector is, therefore, a useful tool in the qualitative and quantitative analysis of gene expression in $B$. fragilis.

\section{References}

AbratT, V. R., Jones, D. T. \& Woods, D. R. (1985). Isolation and physiological characterization of mitomycin C-sensitive/UV-sensitive mutants in Bacteroides fragilis. Journal of General Microbiology 131. 2479-2483.

Aiba, H., AdHya, S. \& DE Crombrugghe, B. (1981). Evidence for two functional gal promoters in intact Escherichia coli cells. Journal of Biological Chemistry 256, 11905-11910.

Boyer, H. B. \& Roulland-Dussoix, D. (1969). A complementation analysis of the restriction and modification of DNA in Escherichia coli. Journal of General Microbiology 41, 459-472.

Feldhaus, M. J., Hwa, V., Cheng, Q. \& Salyers, A. A. (1991). Use of an Escherichia coli $\beta$-glucuronidase gene as a reporter gene for investigation of Bacteroides promoters. Journal of Bacteriology 173. $4540-4543$.

Ghose, T. K. (1987). Measurement of cellulase activities. Pure and Applied Chemistry 59, 257-268.

Gibson, S. A. W. \& Macfarlane, G. T. (1988). Studies on the proteolytic activity of Bacteroides fragilis. Journal of General Microbiology 134, 19-27.

Gornall, A. G., Bardawill, C. J. \& David, M. M. (1949). Determination of serum proteins by means of the biuret reaction. Journal of Biological Chemistry 177, 751-766.

HENIKOFF, S. (1984). Unidirectional digestion with exonuclease III creates targeted breakpoints for DNA sequencing. Gene 28, 351-359.

Hill, R. T., Parker, J. R., Goodman, H. J. K.. Jones, D. T. \& Woods, D. R. (1989). Molecular analysis of a novel glutamine synthetase of the anaerobe Bacteroides fragilis. Joumal of General Microbiology 135, 3271-3279.

Holderman, L. V., Cato, E. P. \& Moore, W. E. C. (editors) (1977). Anaerobe Laboratory Manual, 4th edn. Blacksburg, VA: Virginia Polytechnic Institute and State University Anaerobe Laboratory.

IsH-Horowitz, D. \& BURKE, J. F. (1981). Rapid and efficient cosmid cloning. Nucleic Acids Research 9, 2989-2998.

Macfarlane, G. T., Macfarlane, S. \& Gibson, G. R. (1992), Synthesis and release of proteases by Bacteroides fragilis. Current Microbiology 24, 55-59.

Maniatis, T., Fritsch, E. F. \& Sambrook, J. (1982). Molecular Cloning: a Laboratory Manual. Cold Spring Harbor, NY: Cold Spring Harbor Laboratory

Mossie, K. G., Jones, D. T., RobB, F. T. \& Woods, D. R. (1979). Characterization and mode of action of a bacteriocin produced by a Bacteroides fragilis strain. Antimicrobial Agents and Chemotherap. 16, 724-730. 
Privitera, G., Dublanchet, A. \& Sebald, M. (1979). Transfer of mutiple antibiotic resistance between subspecies of Bacteroides fragilis. Journal of Infectious Diseases 139, 97-101.

SALYERS, A. A. (1984). Bacteroides of the human lower intestinal tract. Annual Review of Microbiology 38, 293-313.

SANGer, F., Nicklen, S. \& Coulsen, A. R. (1977). DNA sequencing with chain terminating inhibitors. Procedings of the National Academy of Sciences of the United States of America 74, 5463-5467.

Shine, J. \& Dalgarno, L. (1976). Determinant of cistron specificity in bacterial ribosomes. Nature, London 254, 34-38.

Shoemaker, N. B., Getty, C., Salyers, A. A. \& Gardiner, J. F. (1985). Evidence that a clindamycin-erythromycin resistance gene of Bacteroides plasmid pBF4 is on a transposable element. Journal of Bacteriology 162, 626-632.

Simon, R., Priefer, U. \& Puhler, A. (1983). A broad-host-range mobilization system for in vivo genetic engineering: transposon mutagenesis in gram-negative bacteria. Bio-Technology 1, 784-794.

Smith, C. J. (1987). Nucleotide sequence analysis of Tn4551: use of ermFS operon fusions to detect promoter activity in Bacteroides fragilis. Journal of Bacteriology 169, 4589-4596.

Southern, J. A., Parker, J. R. \& Woods, D. R. (1986). Expression and purification of glutamine synthetase cloned from Bacteroides fragilis. Journal of General Microbiology 132, 2827-2835.

Southern, J. A., Parker, J. R. \& Woods, D. R. (1987). Novel structure, properties and inactivation of glutamine synthetase cloned from Bacteroides fragilis. Journal of General Microbiology 133, $2437-2446$
Teather, R. M. \& Wood, P. J. (1982). Use of Congo redpolysaccharide interactions in enumeration and characterization of cellulolytic bacteria from the bovine rumen. Applied and Environmental Microbiology 43, 777-780.

Valentine, P. J., Shoemaker, N. B. \& Salyers, A. A. (1988). Mobilization of Bacteroides plasmids by Bacteroides conjugal elements. Journal of Bacteriology 170, 1319-1324.

VAREL, V. H. \& BRYANT, M.P. (1974). Nutritional features of Bacteroides fragilis subsp. fragilis. Applied Microbiology 28, 251-257.

Yamamoto, I., Abe, A., Saito, H. \& Ishimoto, M. (1984). The pathway of ammonia assimilation in Bacteroides fragilis. Journal of General and Applied Microbiology 30, 499-508.

Yamamoto, 1., Saito, H. \& Ishimoto, M. (1987). Regulation of synthesis and reversible inactivation in vivo of dual coenzyme specific glutamate dehydrogenase in Bacteroides fragilis. Journal of General Microbiology 133, 2773-1372.

ZAPPE, H. (1988) The cloning and characterisation of an endoglucanase and an endoxylanase from Clostridium acetobutylicum in Escherichia coli. PhD. thesis, University of Cape Town.

ZAPPE, H., Jones, D. T. \& WoODS, D. R. (1986). Cloning and expression of Clostridium acetobutylicum endoglucanase, cellobiase and amino acid biosynthesis genes in Escherichia coli. Journal of General Microbiology 132, 1367-1372.

ZAPpe, H., Jones, W. A., Jones, D. T. \& Woods, D. R. (1988). Structure of an endo- $\beta$-1,4-glucanase gene from Clostridium acetobutylicum P262 showing homology with endoglucanase genes from Bacillus species. Applied and Environmental Microbiology 54. 1289-1292. 